\title{
Migratory Tendencies in Population of Bank Voles and Description of Migrants *
}

\author{
Michał KOZAKIEWICZ
}

\begin{abstract}
Kozakiewicz M., 1976: Migratory tendencies in population of bank voles and description of migrants. Acta theriol., 21, 24: 321-338 [With 2 Tables \& 6 Figs.].

Capture in pitfalls and removal of bank voles Clethrionomys glareolus (S chreber, 1780) were carried out from July 1971 to October 1972 , obtaining in this way a gap in the population's settlement of the area after 25 days of such trapping. Comparison was made between variations in population numbers, weight, sex and age structures of individuals filling in the gap so created and analogical data obtained during the same period by means of the CMR method for a control population. It was found that the gap in the population's settlement was filled by the entry of migrants, and the continuous capture method applied permits of distinguishing these animals and determining their numbers. The variations in numbers of migrants is due to the variations in numbers of the population and index of migration increases together with increase in population numbers. The ratio of number of males to females is $1: 1$ among the migrants, sexually active individuals predominating among the males, while there is only a small number of pregnant individuals among the females. Migrants constitute a group with a different age structure from that of settled individuals (individuals from 4-6 months old predominate). It was found that the average body weight of migrants is smaller than that of settled voles (in the respective age and sex classes) which is evidence of their physiologically different character.
\end{abstract}

[Dept. Zool. \& Ecol., Warsaw Univ., Krakowskie Przedmieście 26/28, 00-325 Warszawa, Poland]

\section{INTRODUCTION}

Migration within a population is a common phenomenon in populations of small rodents. Many authors have emphasised the differences between migrants and settled individuals in the case of the bank vole Clethrionomys glareolus ( $\mathrm{Schreber}, 1780$ ). Andrzejewski \& W r oc $ł a$ wek (1961) found that migrating voles are characterized by a higher mortality rate in traps than settled individuals, which would indicate that their condition is poorer. These data would appear to agree with the results obtained in Smirin's (1961) studies, in which he

* Praca została wykonana $w$ ramach problemu węzłowego 09.1.7, koordynowanego przez Instytut Ekologii PAN. 
found more intensive metabolism in migrants. J a n i o n (1960a, 1960b, 1961) showed that settled individuals are characterized by a greater variety of flea fauna and a greater degree of infestation than migrating voles. With the voles' transition into a migratory state the numbers of fleas infesting them decrease and their species composition changes, i.e. it is chiefly the fur-living fleas which remain and which are more lastingly connected with their host. P i el o w s ki (1962) found that migrating voles more often fall victim to predators, such as the viper Vipera berus L., than is the case with settled individuals. S r oc z y n s k a (in preparation) conducting parasitological studies on the same material as that used in this paper found more intensive infestation by endoparasites of migrating voles than of settled individuals.

All the above data show that migrants differ from the rest of the vole population. There are, however, no studies in literature giving a more detailed description of migrants, and their numbers are indirectly estimated by calculating the length of time spent by individuals in a study area. The methods so far in use have not permitted of defining exactly which individual currently belongs to the migrant group in a population and thus did not permit of an exact description of this group of animals.

The purpose of the present study is to attempt a qualitative and quantitative description of migrants in a wild population of bank voles, using a method which permitted of direct segregation of migrants from the population.

\section{STUDY AREA, METHODS AND MATERIAL}

The studies were carried out in the Kampinos National Park near Warsaw, simultaneously on two study areas, which were characterized by the occurrence of the same plant associations distributed in a mosaic fashion over the area. The following associations predominated: Carici elongate-Alnetum, coniferous tree stands of the Vaccinio-Piceion alliance (Vaccinio Pinetum molinietosum and Vacciniouliginosi Pinetum), and Pino-Quercetum and Tilio-Carpinetum (Traczyk \& $\mathrm{Traczyk}, 1965)$. The tree stand in each area was about 60 years old.

The assumption on which the actual field work was carried out was that continuous capture and removal of these rodents from a given wooded area causes a gap in settlement by the population by removing all settled individuals from the area. This gap will be filled by migratory individuals entering the study area (Andrzejewski \& Wroclawek, 1962). Continuous trapping in pitfalls and removal of bank voles was therefore carried out on a study area forming a square with sides $240 \mathrm{~m}$ long, which corresponded to the area of 5.76 ha used for capture and removal of rodents by the Standard Minimum method (Grodziński, P ucek \& R y z k owski, 1966). A total of 144 trapping sites were distributed in a grid of $20 \times 20 \mathrm{~m}$ over the area (12 rows of 12 sites each). A metal pitfall of 31 capacity was sunk on each trapping site so that the top rim was on a level with 
the ground surface. The pitfalls contained $1110 \%$ formalin solution, on the surface of which was a thin layer (about $1 \mathrm{~mm}$ ) of rapeseed oil. The formalin served both to kill and conserve the material directly after capture, while the layer of oil reduced evaporation and eliminated the smell of the formalin. The oil was not found either to repel or attract the rodents, since in 5 pitfalls in which (odour-less and taste-less) silicon oil was used instead of rapeseed oil no differences were observed in the number of individuals caught. The formalin solution did not freeze during the winter period. Each pitfall was covered with a wooden cover, which while allowing the rodents easy access, prevented dilution of the formalin solution with rainwater and protected it from falling leaves.

The bank voles were removed from the pitfalls every 5 days, recording the date and place of capture, then rinsed in water with a slight addition of detergent to remove oil residue from the fur and weighed (with accuracy to $1 \mathrm{~g}$ ). After dissection the state of the gonads was determined and the skull and eye-lens prepared. The eye-lenses were fixed in $10 \%$ formalin solution, dried and weighed (Askaner \& Hansson, 1967), also measuring the length of the root of $M_{1}$ in order to determine the age of the animals caught in accordance with the method of Pucek \& Zejda (1968).

Trapping of these rodents in pitfalls was continued without a break from July 1971 to October 1972, during which period a total of 488 bank voles, 56 individuals of Apodemus flavicollis ( $\mathrm{Mel} \mathrm{ch}$ ior, 1834), 33 of Apodemus agrarius ( $\mathrm{Pallas}$, 1771), 1 of Arvicola terrestris ( $\mathrm{L}$ in na e us, 1758), 15 of Micromys minutus (P a lla s, 1778), 5 of Microtus arvalis ( $\mathrm{P}$ a lla s, 1779) were caught, and also sporadically: Sorex araneus (Linnaeus, 1758), Sorex minutus ( $\mathrm{L}$ in na eus, 1770) and Neomys fodiens (Pennant, 1771). Only bank voles, from among all the small mammals caught, were used for the material analysed in the present study.

In October. 1972 the pitfalls were closed and the voles entering the study area permitted to settle. Then, in order to check the effectiveness of capture and removal of settled individuals, in June 1973 live-traps were set out on an area reduced in size to 4.00 ha (10 rows per 10 pitfalls per row) and bank voles trapped and marked individually by toe-clipping. Marking lasted 6 days, a total of 81 voles being marked. Then, the pitfalls were opened and continuous capture and removal of bank voles started again. In the beginning of August 1973 the experiment was finished. 84 voles, in this number 55 previously marked, were caught.

During the period of capture and removal of rodents on the area covered by the pitfall grid observations were made on the second area, treated as a control, of the course taken by variations in numbers and changes in the population's age structure using the $C M R$ method. The material was analysed using the "calendar of catches method (Andrzejewski, 1969). The control area was at first 5.76 ha in size, but in 1972 consisted of three smaller areas $(2.60 \mathrm{ha})$ situated parallel to each other at $45 \mathrm{~m}$ intervals. Live traps distributed in a grid of $15 \times 15 \mathrm{~m}$ were used on these areas, carrying out two-week series of trapping in July, August and October 1971, and in May and July 1972. A detailed description of this area and estimates of population parameters have been given by Mazurkiewicz (1972).

\section{CONFIRMATION OF CORRECTNESS OF ASSUMPTIONS}

Analysis of the results of trapping rodents in pitfalls in successive inspections showed that the number of animals captured decreased 
during the first five removals from the pitfalls, reaching a minimum after 25 days from the time trapping began. After this period the number of animals caught did not decrease but was maintained on a constant level. This suggests that individuals caught during the initial phase of the experiment and during a later phase form two different categories. In order to check the correctness of such a finding it was assumed that the distribution of the number of individuals caught in pitfalis is geometrical in the following form:

where:

$$
P(x=t)=p q^{t-1}
$$

$$
\begin{aligned}
& t=1,2,3 \ldots(5-\text { day unit) } \\
& p=\text { probability of capture } \\
& q=1-p
\end{aligned}
$$

The value of probability $p$ was estimated on the basis of captures of animals during a period not longer than 25 days from the time trapping began, that is after 5 days $(t=1), 10$ days $(t=2), 15$ days $(t=3), 20$ days $(t=4), 25$ days $(t=5)$. The group of individuals caught during the above time interval was given the symbol $N_{1,5}$. The truncate geometrical distribution for $1 \leqslant t \leqslant 5$ (Janion, Ryszkowski \& Wierzbowska, 1968) was considered, taking as a value of probability $p$ estimator value $p^{*}$ calculated according to the equation:

$$
\bar{X}_{1,5}=\frac{q^{*}}{p^{*}}+1-\frac{5 q^{* 5}}{1-q^{*}}=\frac{1}{p^{*}}-\frac{5 q^{* 5}}{1-p^{*}}
$$

where $\mathbb{X}_{1,5}$ is the average time of capture of an animal from group $N_{1,5}$. Value $p^{*}$ from the equation was found by means of the table included in the study by $\mathrm{J}$ a ni o $\mathrm{n}$ et al. (1968). If all animals caught in pitfalls were caught with the same probability $p$ which was estimated for $N_{1,5}$ individuals, then $N^{\prime}=N_{1,5} / 1-q^{* 5}$ animals should be caught. Since in fact far more animals were caught than would be the case using the above equation, it must be assumed that either probability of capture altered after 25 days duration of the experiment, or thiat these differences must be explained by the entry into the trapping area of new individuals from beyond its boundaries. As there are no grounds for finding that probability of capture altered during the course of the experiment it must be taken that the second hypothesis is correct.

The same conclusion can be drawn from analysis of differences between the empirical and theoretical distribution of the number of animals caught. The anticipated theoretical numbers of individuals caught after period $t$ are equal to:

$$
N_{t}=N^{\prime} p^{*} q^{* t-1}
$$

Application of the above equation permits of plotting a theoretical regression curve of the number of animals caught. The course taken by 
this theoretical curve shows how the number of individuals caught in successive inspections would change if all possibilities for voles to enter the study area from outside were eliminated.

Comparison of the curve of capture dynamics of voles from the study area with the theoretical regression curve showed that as from the time the experiment began (19.7.1971) until 10 August 1971 the course taken by the two curves is similar (Fig. 1). As from 10th August 1971 the

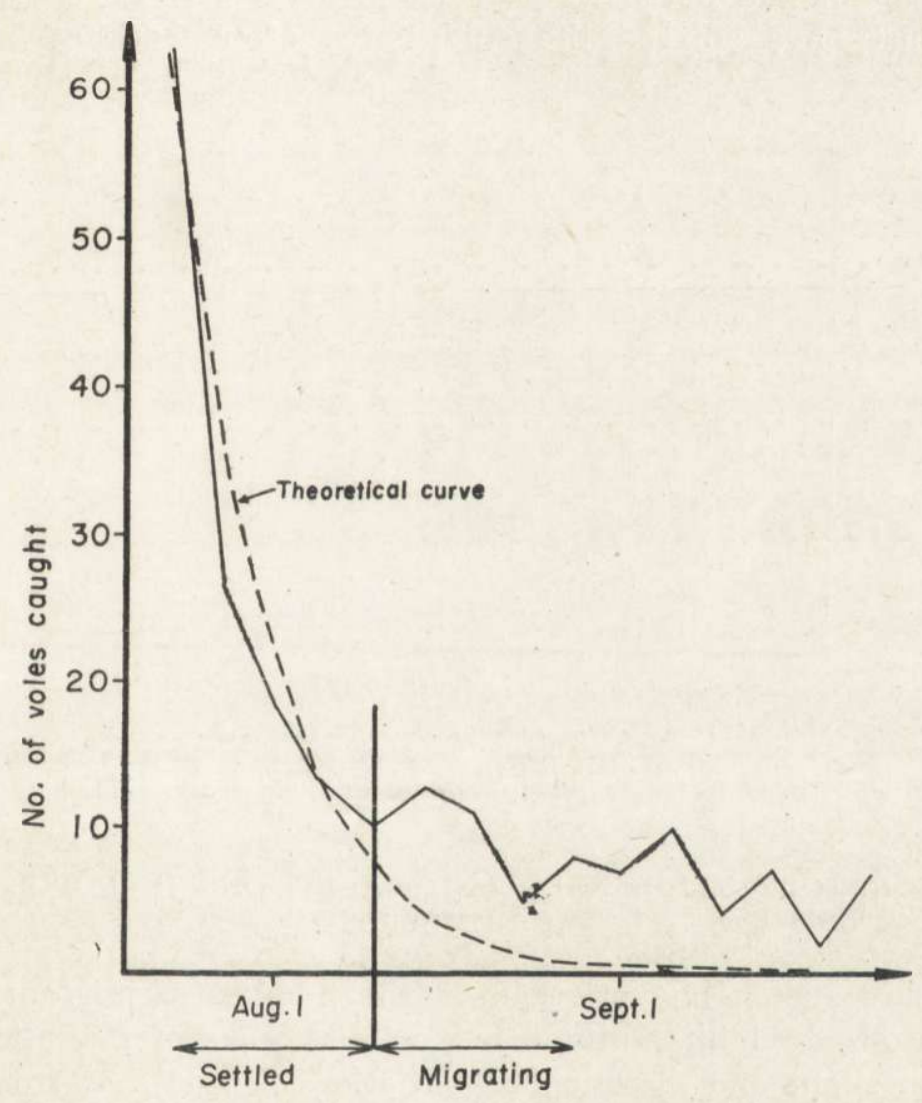

Fig. 1. Comparison of variations in numbers of bank voles caught and removed from the study area with the theoretical regression curve.

number of individuals caught is greater than could be expected from the course of the theoretical regression curve (divergences between theoretical and empirical distributions were checked by means of Pearson's Chi-square test). Increase in the number of individuals caught is undoubtedly due to newcomers entering the trapping area.

It was therefore stated that during the first period of the experiment, 
i.e. up to 10th August 1971, settled individuals were mainly caught, but after this date mainly these which entered the area being treated as migrants. The correctness of the above findings is confirmed by results obtained on the trapping area when a gap in settlement was once again created in July 1973. During the first phase of trappings it was chiefly previously marked individuals which were caught, that is, settled animals. After about 20 days the start of capture and removal the majority of the animals caught had not been previously marked, and were thus voles which must have entered the study area after marking had ceased (Fig. 2).

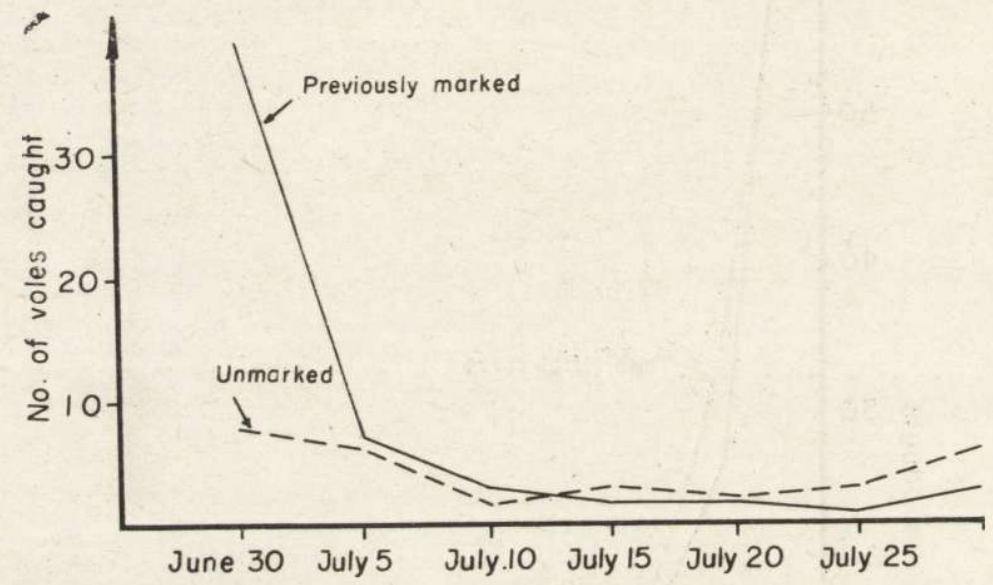

Fig. 2. Capture and removal of bank voles from the study area following the period of marking individual animals (July, 1973).

\section{MIGRATORY TENDENCIES AND VARIATIONS IN POPULATION NUMBERS}

The course taken by variations in the number of migrants entering the study area exhibits autumn and winter peaks of migration in contrast with slight and directionless variations (Fig. 3). As from 20 September 1971 the number of migrants caught begins to rise and reaches a maximum (26 individuals) at the beginning of October. This is the autumn peak of migration in the bank vole population. In December 1971 the number of animals caught in the area again increases and reaches a level of 10 individuals, giving in turn the winter migration peak, caused mainly by old males (Fig. 3 , Table 1 ). After the winter peak period the number of migrants was maintained on a level close to 0 , after which it is again possible to observe an abrupt rise in the number of animals caught. 
Table 1

Comparison of numbers of individuals caught in the study area, arranged in order of birth dates.

\begin{tabular}{|c|c|c|c|c|c|c|c|c|c|c|c|c|c|c|c|c|}
\hline \multirow{3}{*}{$\begin{array}{l}\text { Month of } \\
\text { capture }\end{array}$} & \multicolumn{16}{|c|}{ Month of birth } \\
\hline & & & & 1970 & & & & & & 1971 & & & & & & 1972 \\
\hline & A & M & $\mathrm{J}$ & $\mathbf{J}$ A & S & $\mathrm{O}$ & A & M & $\mathrm{J}$ & $\mathrm{J}$ & A & $\mathrm{S}$ & $\mathrm{O}$ & A & M & $\mathrm{J}$ J A S O \\
\hline July, 1971 & 10 & & & & & 71 & 17 & 39 & 21 & & & & & & & \\
\hline Aug., 1971 & 5 & 2 & & & & & 9 & 19 & 24 & 11 & & & & & & \\
\hline Sept., 1971 & 4 & & & & & & 8 & 7 & 4 & 5 & 2 & & & & & \\
\hline Oct., 1971 & & & & & & & 20 & 32 & & 24 & $\mathbf{5}$ & & & & & \\
\hline Nov., 1971 & 1 & & & & & & 5 & 4 & & 4 & & 1 & & & & \\
\hline Dec., 1971 & & & & & & & 7 & 4 & 1 & & & 1 & & & & \\
\hline Jan., 1972 & & & & & & & & & 1 & & & & & & & \\
\hline Febr., 1972 & & & & & & & 7 & & & & & & & & & \\
\hline March, 1972 & & & & & & & 4 & & & & & & & & & \\
\hline Apr., 1972 & & & & & & & 15 & & & & & & & & & \\
\hline May, 1972 & & & & & & 3 & 4 & & & & & & 1 & 4 & & \\
\hline July, 1972 & & & & & & & 3 & & & & & & 1 & 12 & 5 & 1 \\
\hline Aug., 1972 & & & & & & & & & & & & & & 12 & 4 & \\
\hline Sept., 1972 & & & & & & & & & & & & & & 3 & 24 & $\begin{array}{ll}43 \\
0\end{array}$ \\
\hline Oct., 1972 & & & & & & & & & & & & & & 1 & $3:$ & $\begin{array}{ll}32 \\
2\end{array}$ \\
\hline
\end{tabular}

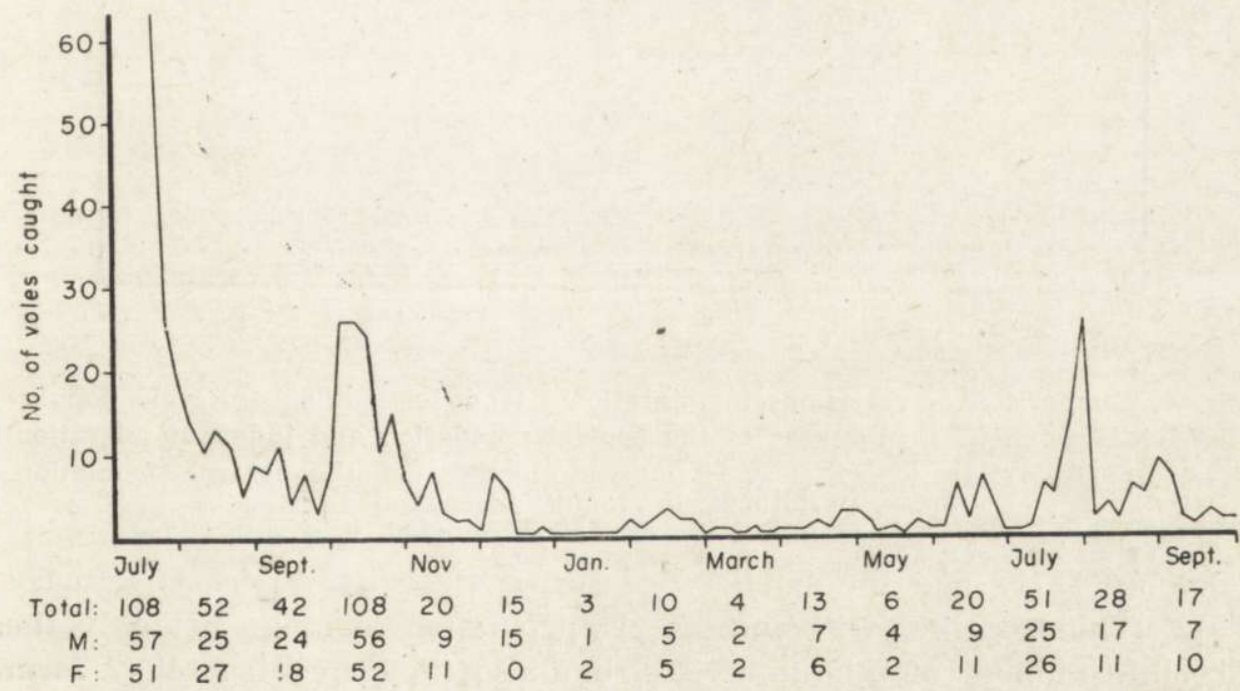

Fig. 3. Variations in captures of bank voles entering the study area.

Comparison on the variations in migration, obtained by continuous trapping of migrants in pitfalls, with variations in population numbers on the control area reveals that the course taken by the two curves is similar (Fig. 4). The general course of migration dynamics coincides with variations in numbers of the control population. The autumn migration 
peaks observed coincide in time with peaks in numbers of the control population.

In order to check whether the percentage formed by migrants in the population changes with changes in numbers, the ratio of number of migrants to number of all animals in the control population, that is, the index of migration, (Petrusewicz, 1963) was determined. The migration index in the bank vole population exhibits variations over the course of the season (Fig. 4). The largest percentage of migrants in the population is found at the time when population numbers are highest

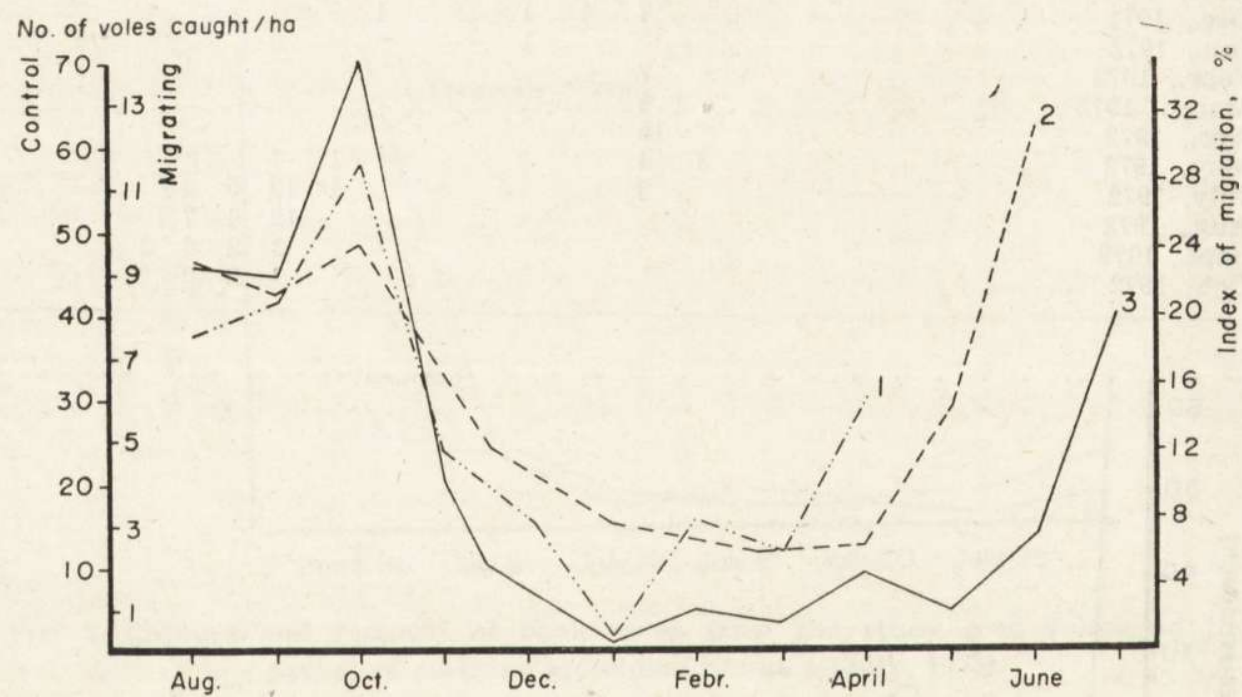

Fig. 4. Comparison of variations in migrational tendencies of a bank vole population with variations in numbers of the control population and index of migration. 1 - index of migration, 2 - variations in numbers of the control population, 3 - variations in migrational tendencies.

(October 1971), and the smallest - during the winter period (January 1972). Thus together with increase in population numbers not only the absolute number of migrants rises, but also the percentage they form of the population.

\section{DESCRIPTION OF MIGRANTS}

\subsection{Sex Structure and Activity}

The voles caught were divided into the following groups according to the state of their gonads:

1. Males - (a) sexually inactive (testes smaller than $6 \mathrm{~mm}$, epididymis 
small, vas deferens thin), (b) sexually active (testes larger than $6 \mathrm{~mm}$, epididymis and vas deferens filled with sperm).

2. Females - (a) sexually inactive (uterus thin) and (b) sexually active, both pregnant and non-pregnant (in which, however, the state of the gonads and genital organs clearly reveals their sexual maturity).

The number of animals caught, both males and females, was similar throughout the whole trapping and removal period (Fig. 2). The ratio of number of males to females in the group of migrant bank voles remains the same as in the settled part of the population, i.e. $1: 1$. Comparison of the percentage formed by sexually active males in the groups of migrant and settled animals shows that sexually active animais decidedly predominate among migrants (Table 2). The percentage of sexually active females among migrants fluctuates within limits of 39 $55 \%$, whereas in the settled group caught at the beginning of the ex-

Table 2

Percentage of sexually active individuals in the group of bank voles caught in pitfalls.

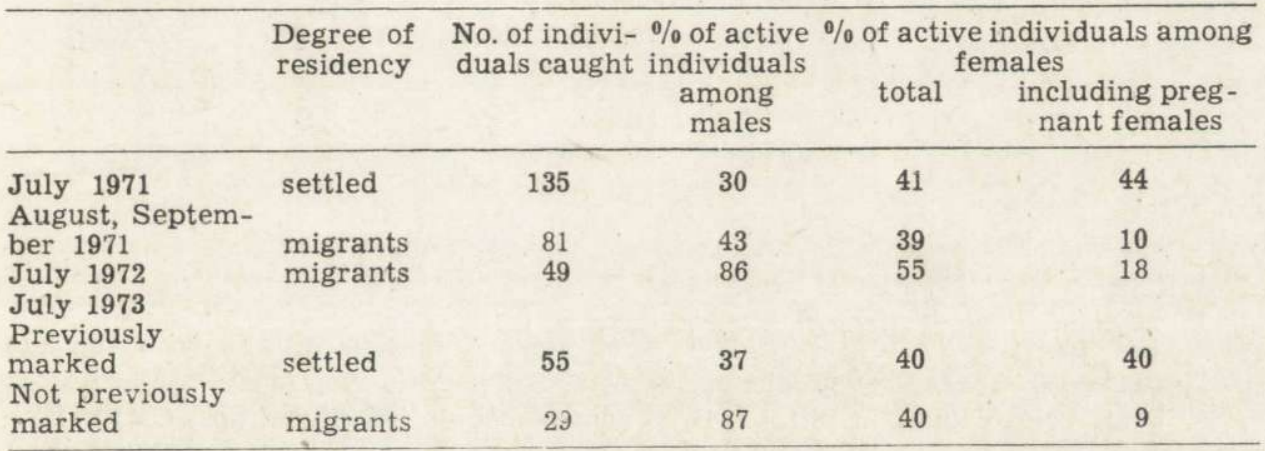

periment, this figure was $40 \%$. If, however, we distinguish the class of pregnant and non-pregnant females in the group of sexually active females, then distinct differences can be found between migrating and settled females. An unusually low percentage of pregnant females was found in the group of sexually active migrating females, whereas a far higher percentage of pregnant females was found in the settled part of the population ('Table 2 ).

\subsection{Age Structure}

The absolute age of the animals caught was determined on the basis of measurement of the dry mass weight of the eye-lens ( $\mathrm{Koz}$ a kie wic z, 1976) and length of the root of $M_{1}$ (P ucek \& $\left.\mathrm{Zejda}, 1968\right)$. By using these two indexes together it proved possible to obtain a far 
more accurate estimated age than when using only one of the above methods.

In the control area newly-marked animals in each trapping series were allocated to the youngest generation, treating them as born during the interval between the preceding and the given trapping series. This group, in addition to the younger individuals, also contained migrants which had entered the study area and certain older individuals not revealed during earlier trapping series. The consequent error in estimating the age of this generation is, however, sufficiently small for this method to be employed ( $\mathrm{Mazurkiewicz}, 1972$ ). It was thus possible to determine successive generations of animals for each trapping series and to give the age structure of the population.

There were no differences in the age structure of the control population in July 1971 and of settled individuals caught during this time

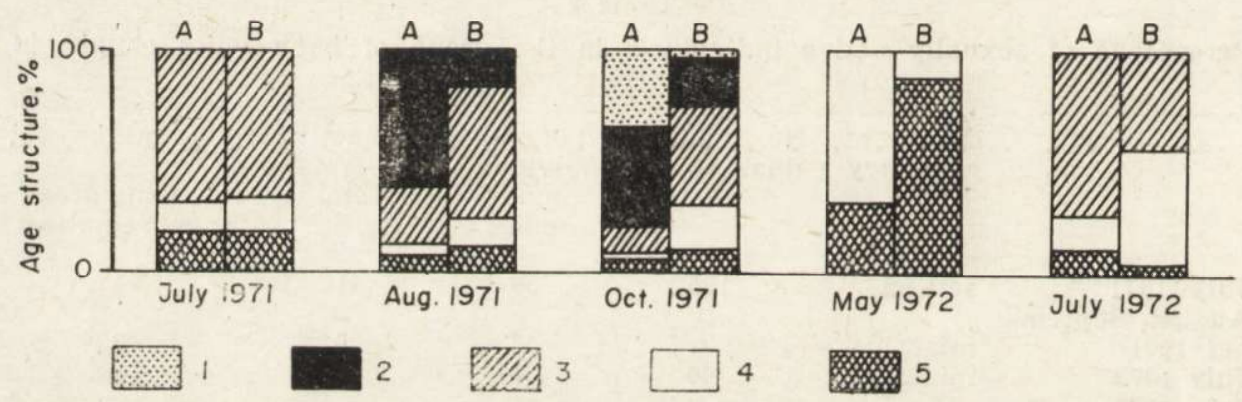

Fig. 5. Comparison of the age structure of voles caught in pitfalls with the age structure of the control population.

A - bank voles caught in pitfalls, B - control population (live traps, CMR), 1 bank voles born in August - September, 2 - voles born in July, 3 - voles born in May - June, 4 - voles born in April, 5 - old adults.

in pitfalls. The age structure of the group of migrating individuals, however, differs from the age structure of the control population in each of the time intervals considered (Fig. 5). A greater percentage of older individuals can always be observed in the migrant group than in the control population. The percentage of the oldest animals does not greatly increase in the group of migrants, whereas age groups of voles from 4--6 months are most numerously represented.

\subsection{Weight Structure}

In order to show how the body weight of voles caught in pitfalls had altered due to immersion in formalin and rinsing, the following experiment was carried out: a group of 15 voles of known weight were placed 
in a pitfall containing $10 \%$ formalin solution with the addition of a little oil, and after five days the voles were rinsed in water to which a detergent had been added and reweighed. The data obtained in this way permitted of determining a coefficient $(w f=1.13 \pm 0.03)$ showing by how many times the body weight of voles increased in the result of

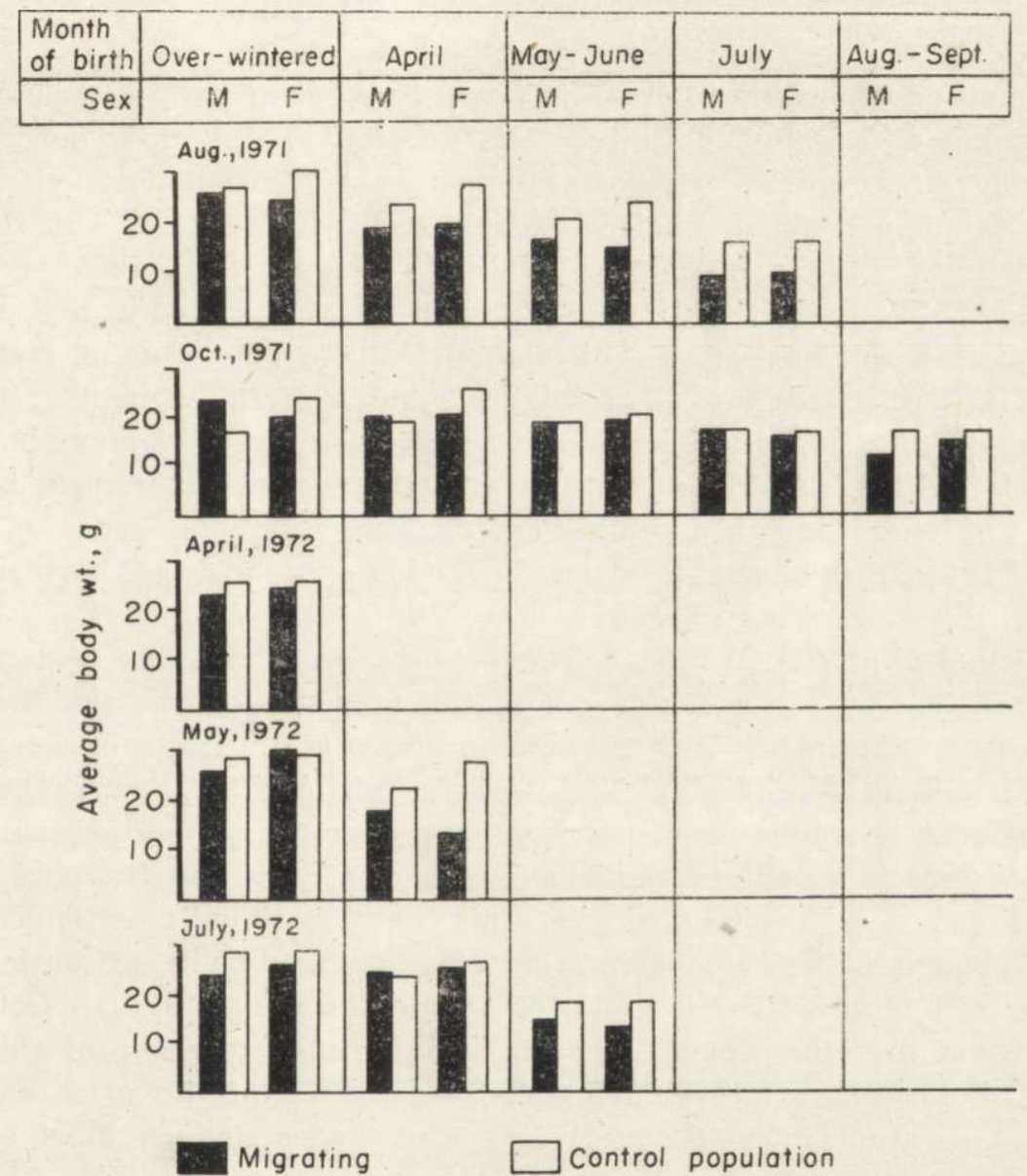

Fig. 6. Comparison of the average body weight of migrant and settled bank voles in corresponding age and sex classes.

being caught in a pitfall containing a formalin solution, and later being rinsed in water. Knowing coefficient $w f$ it was possible to calculate how much each vole weighed at the time of capture.

The average body weight of migrating voles was compared with the mean body weight of animals in corresponding age and sex groups caught 
in the control area (Fig. 6). The average body weight of migrating individuals is as a rule lower than the average body weight of individuals in the settled control population of the same sex and age, although the differences found are not significant in any of the age and sex groups considered.

\section{DISCUSSION}

The method consisting in creating a gap in settlement by a population by catching and removing the animals normally living there has been commonly employed for estimating density and other population parameters in population of small mammals (e.g. Grodziński et al., 1966; A ulak, 1967; Adamczyk \& Ryszkowski, 1968: Pelikan, 1969; Rýs z kowski, 1969). It does, however, create difficulties in estimating the degree to which animals have been caught and removed from the area and gives higher results on the animals density than are in fact the case. This is due to catching not only animals connected with the trapping sector but also the settled individuals in its immediate vicinity and migrants entering the trapping area (Calhoun, 1964; Pelikan, Zejda \& Holišova, 1964; Chełkowska \& Ryszkowski, 1967; Pucek \& Ryszkowski, 1970; $\mathrm{S} \mathrm{mith} \mathrm{et} \mathrm{al.,} \mathrm{1971).} \mathrm{It} \mathrm{must,} \mathrm{however,} \mathrm{be} \mathrm{assumed} \mathrm{that} \mathrm{by} \mathrm{prolonging}$ the period of capture and removal of the animals (as was the case in the present experiment) it is possible to arrive at the state of complete removal of both settled animals within the sector and its surroundings and to treat the animals caught later as migrants. If settled animals were constantly caught in the immediate vicinity of the trapping area it would have to be assumed that this area continually extended its range throughout the whole duration of trapping activities. Continuous capture and removal carried out for 16 months (July 1971 - October 1972) would therefore appear to permit of treating the group of animals caught in pitfalls, after removing the basic stock of the area, as migrants. This group must of course have contained a small number of individuals settled on the periphery of the area.

Comparison of the age structure of animals caught during the first phase of the experiment (treated as settled) and during the later phase (treated as migrants) with the control population structure would appear to provide full confirmation of the correctness of this reansoning. The total lack of differences in the age structure of the control population and voles caught during the first 25 days of capture and removal confirms that it is correct to regard these latter individuals as settled. The occurrence of differences between the age structure of the animals 
caught and removed from the area over the next period of time, and the age structure of the control population in each of the cases considered, suggests that there is no foundatior for the assumption that animals caught at a later phase of the capture and removal procedure are a group of settled animals from the periphery of the area (Fig. 5). If this were the case it would have to be assumed that when the trapping area is deprived of its basic stock only certain age classes of settled animals were caught on its periphery. On the basis of the above findings and data it was agreed to treat the voles entering the study area as migrants.

It must therefore be concluded that application of the method of continuous capture in pitfalls and removal of voles entering the study area should make it possible to obtain a picture of the variations in migratory processes in the population over the yearly cycle, since this method permits of continuous recording of the migration process, as distinct from other methods recording the state (level) of migration only for the period covered by the trapping series, e.g. the method used by A ndrzejewski \& Wi erzbowska $(1960,1961)$.

Quantitative analysis of migrant bank voles revealed constantly occurring small fluctuations in the number of migrants caught (Fig. 3). The winter increase in the number of migrants in the bank vole population is probably the result of the rodents being forced out from the sites they occupy by the periodical rise in the level of ground water in the Kampinos Forest. A n d r ze je w ski (1963), who carried out studies in the same area, observed a similar winter increase in migration in the bank vole population coinciding in time with the periodical rise in ground water level. Bock (1972) found that the bank vole prefers Salici-Franguletum and Circaeo-Alnetum and that old adults, that is, the individuals dominating in the population, occupy preferred habitats in the largest numbers. As it is these habitats which are periodically flooded in the Kampinos Forest the winter increase in migration is caused by the dominants being forced to leave the sites they occupy by the rising level of ground water. Confirmation for the above hypothesis is provided by the fact that the winter increase in migration is caused chiefly by old males, that is, the individuals dominating in the population (Fig. 3, Table 1). Winter migrations in the bank vole population in the Kampinos Forest are therefore caused by abiotic factors and do not depend on population numbers.

The autumn peaks of migration, coinciding in time with peaks of population number, are the evidence of the relation between intensity of migration processes and population numbers in the given period (Fig. 4). Similar results were obtained by Andrze jewski (1963) and G ębczyńska (1966), who found a distinct increase in the number 
of new individuals, not originating from current reproduction, which make their appearance in autumn in a very numerous rodent population. It must, however, be remembered that intensity of migration does not depend only on population numbers. If the number of migrants depended only on the number of animals in a population, the percentage formed by migrants would be constant during the season, and their numbers would vary in accordance with variations in population numbers. The increase in the percentage of migrants found in the present study, together with increase in population numbers, is evidence of intensification of migratory processes with increase in numbers of bank vole populations. Changes in migration index coinciding in time with variations in population numbers justify the assumption that migration may be one of the ways in which the density of the bank vole population is controlled (Fig. 4). Lidicker (1962) has already drawn attention to the existence of the controlling role of migration in animal populations.

Qualitative analysis of bank vole migrants revealed an absence of differences in the sex structure of the settled and migrating parts of the population (Fig. 3). Andrzejewski \& Petrusewicz (1962) found in a house mouse population, and Ryszkowski (1962) in a coypu population, that the percentage of males was greater in the group of migrating individuals than in the group of settled animals. As a result the ratio of males to females in the case of migrants is approximately $1: 1$, while females predominate in the group of settled individuals. $\mathrm{F}$ i t $\mathrm{ch}$ (1948) also found a greater tendency to migration to considerable distances among males in a ground-squirrel population. The absence of the oldest generation in the migrant group of animals, found in the present study, justifies the suggestion that these are dominants in the population which are characterized by close connection with the area (Andrzejewski, Petrusewicz \& Waszkiewicz-Gliwicz. $1967)$, and therefore by a high degree of residency.

Comparison of the migrants' age structure with that of the control population showed that older individuals predominate in the group of migrating individuals (Fig. 5). The age structure of the control population, however, may be "rejuvenated ", since all newly-marked individuals in the given trapping series were allocated to the youngest generation. In addition to bank voles born during the interval between different trapping series, this group may also include migrants which had entered the study area and certain settled individuals present in the population even during the preceding trapping series, but not revealed as present until the subsequent series. It seems, however, that the resulting error with which the data representing the age structure of the control population are burdened,' is not sufficiently great to justify 
complete disregard of the differences obtained in the age structure of the migrating and settled groups. Evidence of this is provided by the similarity of the age structure in the group of settled individuals caught in and removed from pitfalls at the beginning of the experiment with the age structure of the control population during this time (Fig. 5). Mazurkiewicz (1972) in comparing the weight structure of individuals caught for the first time in an island and an open population showed that in the latter case it corresponded to the weight distribution of older individuals about 1.5 months oid. Differences in weight structure in this group of individuals are due chiefly to the lack of opportunity to migrate in the case of the island population. Thus the error made in defining the age of the youngest generation in an open population may be about 1.5 months, this being the degree of error which may occur due to the lack of accuracy of the method for estimating the age of the control population employed in the present study.

Individuals from 4-6 months old predominate in the group of migrants, while the youngest bank voles form a group least numerously represented. Nikitin a (1970) states that in populations of small rodents young individuals occupy the mother's home range. It is not until they attain sexual maturity that they leave the range and possibly change to a migratory state. Nikitina's (1970) data would appear to agree with the results obtained in the present experiment.

The smaller average body weight of migrants than of the settled groups of the same age and sex (control population) would appear to point to the poorer condition of migrants (Fig. 6). The higher mortality in traps of migrating individuals (Andrzejewski \& Wrocławek, 1961) and the more intensive metabolism ( $\mathrm{S}$ mirin, 1961) seem to provide confirmation of this hypothesis. It is difficult to decide whether the migrants' poorer condition is the cause or the result of a migratory way of life. On the one hand the statement that weaker individuals in poorer condition are ousted from the population and that it is they which from the migrant group would appear correct. On the other hand migrating animals, that is, animals, without their own home range, encounter greater difficulties in finding food, do not have their own nests and consequently the different living conditions contribute to deterioration in the condition of this group of bank voles. It would therefore appea: correct to find only the physiological differences in the migrant group as one of the characteristics proper to this group of animals.

Acknowledgments: My thanks are due to Dr. M. Mazurkiewicz and Dr. R. Andrzejewski for the assistance and guidance given to me during work on this paper and for their valuable advice on the subject itself and the methods employed. 


\section{REFERENCES}

1. Adamczyk K. \& Ryszkowski L., 1968: Estimation of the density of a rodent population using stained bait. Ekol. pol. A, 15: 737-746.

2. Andrzejewski R., 1963: Processes of incoming, settlement and disappearance of individuals and variations in the numbers of small rodents. Acta theriol., 7: 169-213.

3. Andrzejewski R., 1969: Analiza wyników połowów drobnych ssaków metodą „kalendarza złowien”. Zeszyty Naukowe I. E. PAN, 2: 1-104.

4. Andrzejewski R. \& Petrusewicz K., 1962: Natural history of a freeliving population of house mice (Mus musculus Linnaeus) with particular reference to groupings within the population. Ekol. pol. A, 10: 85-122.

5. Andrzejewski R., Petrusewicz K. \& Waszkiewicz-Gliwicz J., 1967: The trappability of Clethrionomys glareolus (S chreber, 1780) and other ecological parameters obtained by the C. M. R. capture method. Ekol. pol. A, 15: $710-725$.

6. Andrzejewski R. \& Wierzbowska T., 1960: On the degree of residency and migrancy in the population of small rodents. Bull. Acad. Pol. Sci., Cl. If, 8, 7: 293-296.

7. Andrzejewski R. \& Wierzbowska T., 1961: An attempt of assessing the duration of residence of small rodents in a defined forest area, and the rate of interchange between individuals. Acta theriol., 5, 12: 153-172.

8. Andrzejewski R. \& Wroclawek H., 1961: Mortality of small rodents in traps as an indication of the deminished resistance of the migrating part of population. Bull. Acad. Pol. Sci., Cl. II, 9, 12: 491-492.

9. Andrzejewski R. \& Wroclawek H., 1962: Settling by small rodents a terrain in which catching out had been performed. Acta theriol., 6, 9: 257 -274 .

10. Askaner T. \& Hanss on L., 1967: The eye lens as an age indicator in small rodents. Oikos, 18: 151-153.

11. A u la k W., 1967: Estimation of small mammal density in three forest biotopes. Ekol. pol. A, 15: 755-778.

12. Bock E., 1972: Use of forest associations by bank vole population. Acta theriol., 17, 16: 203-219.

13. Calh ou n J. B., 1964: The social use of space. [In: „Physiological mammalogys, Eds Mayer W. V. \& Gelder R. G. van], 1: 1-187. Academic Press, New York and London.

14. Chełkowska H. \& Ryszkowski L., 1967: Causes of higher abundance estimates of small rodents at the edges of sampling areas in forest ecosystems. Ekol. pol. A, 15, 37: 737-747.

15. Fitch H., 1948: Ecology of the California ground-squirrel of grazing lands. Am. Midl. Nat., 39: 513-596.

16. G ę bczyńska Z., 1966: Estimation of rodent numbers in a plot of Querco-Carpinetum forest. Acta theriol., 11, 11: 315-328.

17. Grodziński W., Pucek Z. \& R yszkowski L., 1966: Estimation of rodent numbers by means of prebaiting and intensive removal. Acta theriol., 11: $297-314$.

18. J a n i on S. M., 1960a: Flea infestation of three species of mice: Clethrionomys glareolus, Apodemus agrarius and Apodemus flavicollis during particular weeks 
of their occurrence of the experimental area. Bull. Acad. Pol. Sci., Cl. II, 8: $363-367$.

19. Janion S. M., 1960b: Quantitative dynamics in fleas (Aphaniptera) infesting mice of Puszcza Kampinoska. Bull. Acad. Pol. Sci., Cl. II. 8: 213-218.

20. J a n i o n S. M., 1961: Studies on the differentiation of a house mice population according to the occurrence of fleas (Aphaniptera). Bull. Acad. Pol. Sci., Cl. II, 9, 12: $501-506$.

21. Janion S. M., Ryszkowski L. \& Wierzbowska T., 1968: Estimate of number of rodents with variable probability of capture. Acta theriol., 13, 16: $285-294$.

22. Kozakiewicz M., 1976: The weight of eye lens as the proposed age indicator of the bank vole. Acta theriol. 21: $314-316$.

23. Lidicker W. Z., 1962: Emigration as a possible mechanism permitting the regulation of population density below carrying capacity. Am. Midl. Nat., 96: 29-33.

24. Mazurkiewicz M., 1972: Density and weight structure of populations of the bank vole in open and enclosed areas. Acta theriol., 17, 34: 455-465.

25. N ikitin a N. A., 1970: O postojanstve izpolzovanija territorii gryzunami. Fauna i ekologija gryzunov, 9: 110-133.

26. Pelikán J., 1969: Edge effect of sampling area. [In: „Energy flow through small mammal populations«, Eds. K. Petrusewicz \& L. Ryszkowski]. Polish. Sci. Publ.: 57-63. Warszawa.

27. Pelikán J., Zejda J. \& Holišova V., 1964: On the question of investigating small mammal populations by the quadrate method. Acta theriol. 11: $1-24$.

28. Petrusewicz K., 1963: Zagajenie sympozjum poświęconego zagadnieniom migracji. Ekol. pol. B, 9: 125-129.

29. P i e lows k i Z., 1962: Untersuchungen über die Okologie der Kreuzotter (Vipera berus L.). Zool. Jb., Syst., 89: 479-500.

30. P u cek Z. \& Z e j d a J., 1968: Technique for determining age in the Red-backed vole, Clethrionomys glareolus (S chreber, 1780). Small Mammal Newslett., 2, 4: $51-60$.

31. Pucek Z. \& Ryszkowski L., 1970: Polskie badania nad produktywnością drobnych ssaków. Kosmos A, 2: 197-213.

32. R y s k ow ski L., 1962: Differences in trapping frequency of coypu. Bull. Acad. Pol. Sci., Cl. II, 10: 19-94.

33. Ryszkowski L., 1969: Operation of the Standard Minimum Method. [In: »Energy flow through small mammal populations", Eds. K. Petrusewicz \& L. Ryszkowski]. Polish Sci. Publ.: 13-25. Warszawa.

34. Smirin J. M., 1961: Osobennosti termoregulacji myševidnyh gryzunov, obitajuščih v različnyh tipah lesa Podmoskovja. Pervoe vsjesojuz. Sovešč. po Mlekopit., 2: 87-88.

35. Smith H. M., Blessing R., Chelton J. G., Gentry J. B., Golley F. B. \& Mc Ginnis J. T., 1971: Determining density for small mammal populations using a grid and assessment lines. Acta theriol., 16: 105-125.

36. Tracz y k H. \& Tra cz y k T., 1965: Charakterystyka fitosocjologiczna terenów badawczych I. E. PAN w Dziekanowie Leśnym (Puszcza Kampinoska). Fragm. Flor. Geobot., 11, 4: 547-562.

Accepted, February 17, 1976. 
Michał KOZAKIEWICZ

\section{MIGRACYJNOSĆ POPULACJI I CHARAKTERYSTYKA MIGRANTÓW NORNICY RUDEJ}

\section{Streszczenie}

Badania prowadzono w Dziekanowie Leśnym (Puszcza Kampinoska) jednocześnie na dwóch powierzchniach badawczych. Na pierwszej z nich ( 5,76 ha) rozstawiono w sieci $20 \times 20 \mathrm{~m}$ cylindry zawierające $10 \%$ roztwór formaliny. Odłowy nornic w cylindry prowadzono bez przerwy od lipca 1971 r. do października 1972 r., uzyskując po 25 dniach lukę w zasiedlaniu populacji (Fig. 1). Badano dynamikę liczebności, strukturę: ciężarów, płciową i wiekową osobników wypełniających wytworzoną lukę, porównując je z danymi uzyskanymi metodą $C M R$ na drugiej powierzchni traktowanej jako kontrolna.

Stwierdzono, że w okresie wytwarzania luki w zasiedleniu populacji łowiono głównie osobniki osiadłe, zaś po tym okresie - głównie migranty. Dynamika nachodzenia migrantów na powierzchnię badawczą wykazuje jesienne i zimowe szczyty liczebności. Szczyty zimowe spowodowane głównie przez stare sannce dominujące w populacji (Tabela 1, Fig. 3) są niezależne od liczebności populacji. Szczyty jesienne są związane z jesiennymi wzrostami liczebności populacji (Fig. 4). Stwierdzono również wzrost wskaźnika migracyjności wraz ze wzrostem liczebności populacji. Stwierdzono, że w grupie migrantów stosunek płci wynosi $1: 1$, wśród samców przeważają aktywne płciowo, wśród samic występuje mała liczba ciężarnych (Tabela 2). Struktura wiekowa migrantów jest „przesunięta” w kierunku osobników starszych w porównaniu ze strukturą wiekową populacji osiadłej (Fig. 5). Struktura ciężarów w grupie migrantów (w odpowiednich klasach wieku i płci) jest z reguły „lżejsza” niż w grupie osobników osiadłych (Fig. 6). 